\title{
紙質におよぼす叨解の影響についで
}

\author{
山口德一郎 ${ }^{* *}$ •戸田敬文・吉田泰二
}

\section{The Influence of Beating on Paper Properties}

\author{
Tokuichiro Yamaguchi, Takafumi Toda and Taiji Yoshida
}

Hemicellulose in L-BKP and N-BKP was individually extracted with various kinds of alkali solutions. Handsheets were made by a beater run in Pebble mill and physical properties were determined (tested for basis weight, thickness, bursting strength, Elmendorf tearing resistance, tensile strength, folding endurance, apparent density by Calculation, porosity, oil absorbency, opacity and Canadian standard freeness etc.) samples were made as follows.

a. Basis was L-BKP slightly beaten by Valley beater.

b. Sample with suitable freeness were prepared after blending hardly beaten L-BKP with basis.

c. Sample with suitable freeness were prepared after blending hardly beaten N-BKP with basis.

Physical properties of the sample which was beaten in Lampen mill were determined.

N-BKP と L-BKP 中に含有されているいわゆるへ ミセルローと称するものが，稀アルカリ液濃度のらが ったものによって溶出される状況につき検討し，続い て単独吒解の場合と，へミセルを接着凮的に考えて抄 紙した場合とを比較し，われわれはそれらの特質をど のように利用すべきかについて資料となり得るいくつ かの参考データを示した。

\section{緒言}

紙の物理的性質に吒解処理が大きく影響することは 一般に認めるところである。

さてその因子について従来多くの専門家が研究を重 ねている。例えば，W. Boyd Campbell(1) は研究の結 果として, 繊維の結合は有効面積, 接触掞よび水素結 合の三因子が関係することを説さ，Bengt G. Rånby (2) (3) はミセル糸状構造について詳細な研究を行なった。 Asumman, Saara, \& Steenberg Börje ${ }^{(4)}$ は電子顕微 鏡を駆使して，繊維の微細構造について攻究し， H. W. Emerton(5) は電子顕微鏡のたすけをかりで，繊維 の構造から繊維の徽細部分を究め, その中のへミセル ロースの作用から膨閏，物理的性質の広範甩にわたっ て繊維の吒解理論を述べた。James O. Thempson, John W. Swanson and Louis Wise ${ }^{(6)} ら は$ 多種類の研 究を行ない，膠着剤としてのへミセルロースについて それらの効果を検討した。その他多くの研究者達は針

* 原稿受付 昭 40.3 .10

** 日本紙業株式会社研究所
・広葉樹両繊維につき詳細にわたって紙葉の特質につ さ研究をほり下げていった。その 1 例を示すと, Ferdinand Wultch \& Rudlf Schmut ${ }^{(7)} ら$ Valley beater, pebble mill および Klark kollergangを用いて繊 維に与える影響を研究した。John A. Mcpherson \& Olov E. Öhrn(8) らはS P およびK P中に含有されて いるHemicell の相違を研究している。結局, 紙葉に 特徵を与えるものは, 繊維中の多糖類であるへミセル が膠着剂として役立つ。したがって例えば，破裂強度 を要求するもの, 引裂度を望むもの, 不透明度を欲す るもの, 吸水性を必要とするものなど, その特質の要 求に応じて，機械設備や製造技術の最適の条件が満た されなければならない。

ところでわれわれもまた吒解の変化が紙質におよぼ す影響の一端を知るために試験用 Pebble mill, Lampen mill 执よび Valley beaterを用いN-BKP, L-BK $\mathrm{P}$ についての検討を試みた。

\section{実験}

I. $\mathrm{NaOH}$ 溶液によるパルプ中の抽出物について L-BKP と N-BKP を別々に, $\mathrm{NaOH}$ 溶液による抽 出状況の相違を検討した。アルカリ溶液抽出物すなわ ち俗にいうへミセルロースといわれる語は，1891 年 Schulze ${ }^{(9)}$ によって生まれて以来多くの人々によって $\mathrm{KOH}$ を用いたり， $\mathrm{NaOH}$ を使用したり，薬液の濃度， 操作法のいろいろが採用された文献が多数発表されて いる。例えばパルプ化に使用された材種, 蒸募法の相 違，精製法のちがいあるいは多糖類の分別など，そし 
てそれらの関係が研究されている。参考までにそのい くつかを引用して見よう。

Francis D. Ratlift ${ }^{(9)}$ は $5 \% \mathrm{KOH}$ 溶液でパルプ中 の溶解物を測定してその值をへミセル A とし，24\% $\mathrm{KOH}$ 溶液に溶出したものをへミセル Bとしてパルプ の性質を論じている。James D. Wethern ${ }^{(10)}$ は Black spruce を用いて $5 \% ， 16 \%$ $\mathrm{KOH}$ 溶液， $20^{\circ} \mathrm{C} ， 2$ 時間窒素瓦斯下で各ホロセルロースから 2 つフラク ションを造るために連続的に抽出を行なった。

James O.Thompson ${ }^{(6)}$ らは Aspen, Black spruce, Douglas fir および Slashpineなどよりの抽出物を用 いて，ビータ一添加量による強度試験を追究している。 Manual N. Fineman ${ }^{(11)}$ は水に膨潤しアルカリ液に溶 解するへミセルの抄紙性におよぼす種々のデーターを 提出した。L.G. Cottrall(12) によればへミセルを全然 含有しない非可逆性の純粋な繊維素繊維はビーターバ 一でカッティングを受け易いが，可塑性をもった繊維 は吒解でフィブリル化する傾向があることを，ボロや 晒サルファイトパルプについて多くの抄紙性を論じて いる。 Russel Nolson'(13) は3, 10 および $18 \%$ Na $\mathrm{OH}$ でいわゆるへミセルロースを抽出し, $\mathrm{NaOH}$ 溶液 $3 \%$ 時にはキシロースが多く抽出され， $\mathrm{NaOH}$ 溶液 18\%の時にはマンノースが多く抽出されていたといい， Dr. Louis E. Wise(14) はK P と S Pのへミセルロース 的相違を論じている中で Jayme の仮説を述べている。 それによるとK P のへミセルロースとリグニンは全細 胞壁を通して中間層からルーメンまで全く規則的に分 布しているが，SPの場合のへミセルロースは繊維の 表面に集中している（細胞の最外層にある），また針 葉樹 K P はほとんどウロナイド・ヘミセルロースを含 んでいないといわれる。Olov E. Öhrn \& Barbro E. Enström(15) らは Birch pulp のへミセルロースにつ いて述べている。すなわちアルカリ溶液の $10 \%, 18 \%$

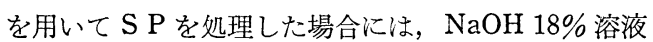
で処理した時のへミセルロースの収率は最高を示した と発表, John A. Mopherson \& Olov E. Öhrn ${ }^{(16)}$ に よれば硫酸塩パルプの場合へミセルロースの全収率は $10 \% \mathrm{NaOH}$ で最高を示した。これに反して S P の場 合の収率は $18 \%$ と $10 \% \mathrm{NaOH}$ 溶液で大体同じであっ たといわれる。Göran E. Annergren, Sven A. Rydh$\operatorname{olm}^{(7)}$ らの研究によれば，クラフトパルプ中のキシ ランは元の木材中のへミセルロース中のものより割合 が高くなっているといわれる。Ferdinand Wulsch, Rudolf Schmut(7) らはまた Valley beater, Krark Kollergang および Pebble mill による紙質の変化を 比較している。近年ビーター型のものはだんだん少な
くなりコニカルリファイナー式のものが多く使用され るようだが，吒解処理に関する限りやはり刃のエッヂ の構造と材質によって瀻維に種々らがった影響を与え るだろう。Bengt Leopold(18) は Loblolly pine を秋 材と春材にわけて，それらの繊維から $\mathrm{KOH}$ 溶液で $0.1 \mathrm{~N}, 0.4 \mathrm{~N}, 1.5 \mathrm{~N}$ あるいはこの $\mathrm{KOH}$ に $\mathrm{H}_{3} \mathrm{BO}_{3}$ を添 加したものなどを用いて抽出を行なったり，抽出物を 各種単糖に分別している。それによると秋材部の繊維

Relation between alkali solubility and $\mathrm{NaOH}$ consistency

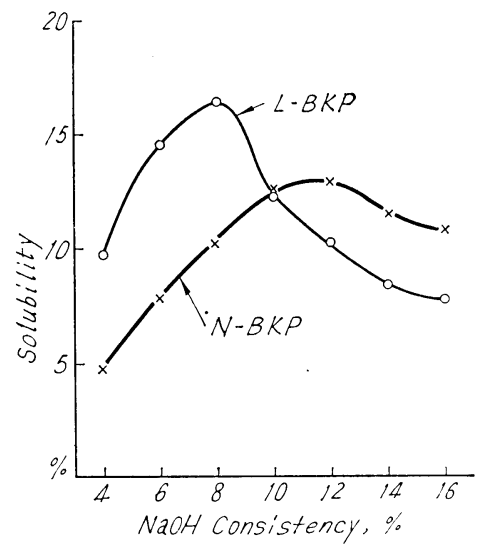

Fig. I-1

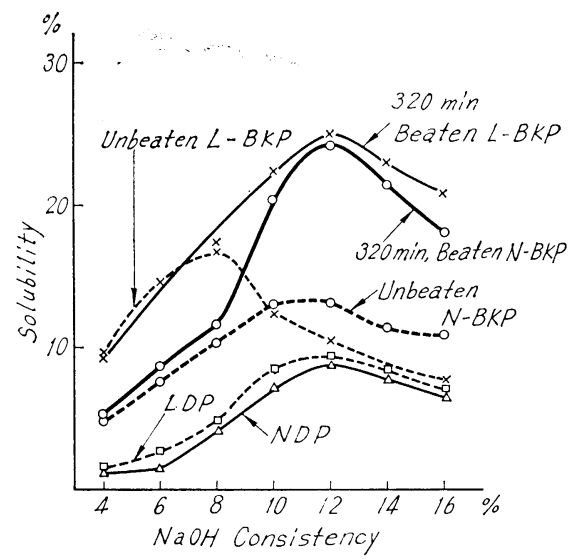

Fig. I-2

中には多量のマンナンが含有されていたと報じた。最 近戸田(19) らもへミセルロースについて多くの貴重な 研究を行なっている。

以上のごとくパルプ中の多糖類をアルカリで処理し た研究の文献はこのほか相当沢山ある。以下に示した ものは，われわれが N-BKP と L-BKP につき種々条 件をかえて検討を行なって見たものである。ただし， 各種単糖への分別処理は一応後期に譲ることにした。 
まず 4，6，8，10，12，14 おちよ゙ $16 \% \mathrm{NaOH}$ 溶液に よる $20^{\circ} \mathrm{C}$ に和ける溶出率の比較を Fig. I-1 に示した。

Fig. I-1 に示す如く，この実験では，未吒解の LBKP の場合 $\mathrm{NaOH}$ 溶液 $8 \%$ のころに，また同じく 未吒解の N-BKP の場合には $\mathrm{NaOH}$ 溶液 $12 \%$ とこ ろにピークがあった。したがって $\mathrm{NaOH}$ 溶液による 溶解度測定ではLの場合に $\mathrm{NaOH}$ 溶液は $8 \%$ を，ま た $\mathrm{N}$ の場合には $12 \%$ の $\mathrm{NaOH}$ 溶液を使用することに した。

ついでながら L-DP, N-DP 並びに L-BKP および N-BKP をそれぞれ 320 分吒解したタのについて， $\mathrm{NaOH}$ 溶液の抽出を行なって見たところ次のような結 果となった。(Fig. I-2)

Fig. I-2 を見ると, LDP, NDP，320 分吒解したL$\mathrm{BKP}$ 並びに N-BKP の 4 種はいずれも $12 \% \mathrm{NaOH}$ 溶 液のところにピークがある。320 分吒解したものはま た， $10 \% \mathrm{NaOH}$ 溶解での抽出量は $20 \%$ 以上の数值を 示したことについては，アルカリ処理後の抽出液分離 にあたって，6000回/分の円心分離器を使用したが微 細な繊維の分離がじゅうぶんできなかったことが一原 因のよらに考光られる。

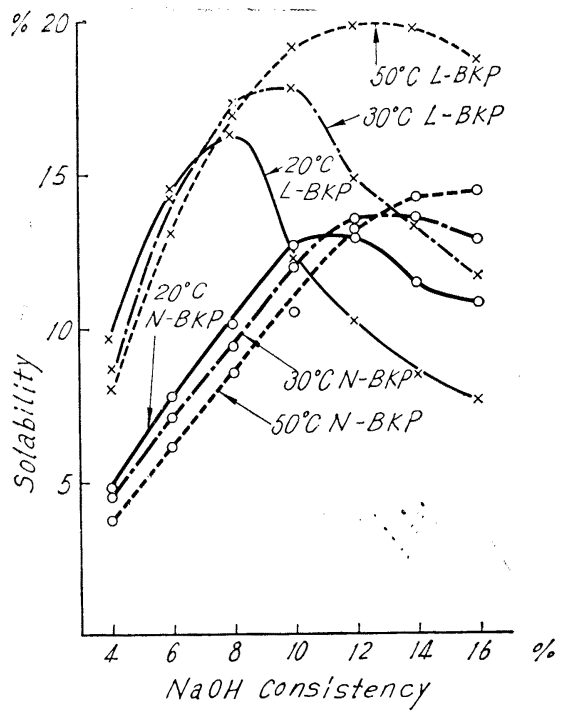

Fig. I-3

次に $20^{\circ}, 30^{\circ}$ および $50^{\circ} \mathrm{C}$ における $\mathrm{NaOH}$ の濃度 変化による溶出率を測定した（Fig .I-3）。

Fig. I-3 に示すごとく，抽出温度を高くすると，そ れぞれピークは $\mathrm{NaOH}$ 濃度の高い方へ移行し， $\mathrm{NaO}$

$\mathrm{H}$ 溶液による溶解度も上昇した。

次に従来 $\mathrm{NaOH}$ 溶液による繊維素の膨潤率は L-B $\mathrm{KP}$ む $\mathrm{N}-\mathrm{BKP}$ もとに $20^{\circ} \mathrm{C}$ の場合が $50^{\circ} \mathrm{C}$ の場合よ りも大きいといわれていたが，各アルカリ濃度におけ
るものについて測定したところ $20^{\circ} \mathrm{C}$ においては，あ る程度までは高い傾向にあるが，抽出液の温度が高く なるにつれ，液濃度の高い方へピークも移動している 傾向にある。これはより高い処理温度ではセルロース の低分子化が起きて溶出されるものが多いと見られて いる。

Table I-1 Relationship between swelling and alkali concistency

\begin{tabular}{|c|c|c|c|}
\hline Sample & $\begin{array}{c}\text { Concistency } \\
\text { of NaOH sol. } \\
\%\end{array}$ & \multicolumn{2}{|c|}{$\begin{array}{c}\text { Swelling Ratio \% } \\
\text { L-BKP }\end{array}$} \\
\hline 4 & $\begin{array}{c}\text { at treating } \\
20^{\circ} \mathrm{C}\end{array}$ & temp. $50^{\circ} \mathrm{C}$ \\
\hline 8 & 150.1 & 140.8 \\
12 & 147.4 & 137.9 \\
16 & 152.7 & 146.3 \\
4 & 155.4 & 145.6 \\
8 & 133.4 & 125.3 \\
12 & 160.4 & 145.9 \\
16 & 162.4 & 146.0 \\
\hline
\end{tabular}

処理方法：処定の $\mathrm{NaOH}$ 濃度で $20^{\circ} \mathrm{C}, 50^{\circ} \mathrm{C}$ 別々に 処理し，それぞれの温度水で水洗し， 4000 回/分で $20^{\circ} \mathrm{C}, 50^{\circ} \mathrm{C}$ 処理物を同時脱 水した。科量の後パルプは絶乾量を求め 円心脱水後のパルプ量 $\times 100 \%$ パルプ絶乾星

で表示した。

繊維の膨潤について H. W. Emerton ${ }^{(5)}$ は, 多糖類 よりなる非結晶領域中に水が浸透すると述べまた James P. Casey の Pulp \& Paper, Vol. II ${ }^{(20)}$ 中に Young \& Roland の報告がある，それによればN材パル プのペントース含有量と膨潤との間にはほとんど直線 関係があるが，L材パルプの場合にはそれがないと。 かつて Kress and Bialkowsky(21) らは Spruce によ る Mitscherlich 亚硫酸末晒パルプを用い種々な溶媒

Table I-2 種々の溶媒中に和ける S P の膨潤能

\begin{tabular}{|c|c|}
\hline 溶媒 & 増加した容積 \% \\
\hline フォルムアマイド & 125 \\
\hline & 90 \\
\hline エチレング!コール & 89 \\
\hline メチルアルコール & 62 \\
\hline エチルアルコール & 40 \\
\hline$n$ nープロピールアルコール & 6 \\
\hline$n$-ブチルアルコール & 4 \\
\hline フル ラ ラ ル & 8 \\
\hline フルフリールアルコール & 51 \\
\hline 料 & 2 \\
\hline$\Gamma \quad=\quad y$ & 15 \\
\hline
\end{tabular}


中に括ける繊維の膨潤能を测定している，その内から いくつかを抜萃するとTable I-2 に示したごとくであ る。これはそれぞれの純溶媒中で测定し最大澎潤を示 したものである。

パルプの膨㵎能はその永酸基によるもので，繊維は 水, ホルムアマイド，エチレングリコールのような高 度の極性液体中で相当膨閵するが，非極性液体中では 膨潤しない。また第 1 次膜が除去されて第 2 次膜が現 われた形となると径が 2 〜倍にも膨潤することが記 されている。

われわれは未印解の N-BKP と L-BKP を我中に保 持して，円心分離法で処理し保水度を測定したところ， われわれの用いたサンプルと方法に関する限り有意の 差は見られなかったが，吒解による瀻維の最大の膨潤 能としては改めてもっと詳細に榆討する必要があるよ らに思う。

次に処理時間による抽出量の変化は Fig. I-4 に示 した。同図によれば，L-BKP と N-BKP もともに抽

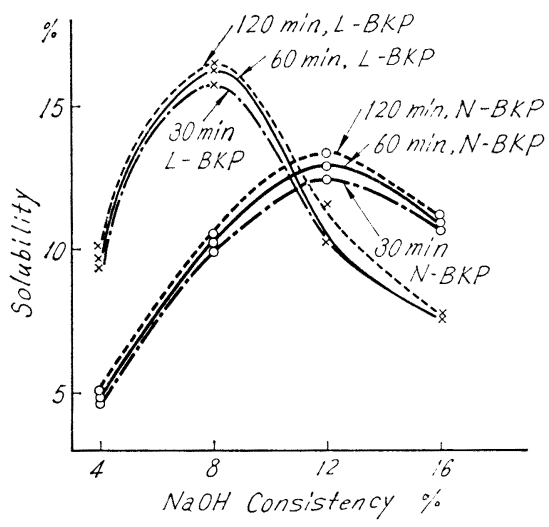

Fig. I-4

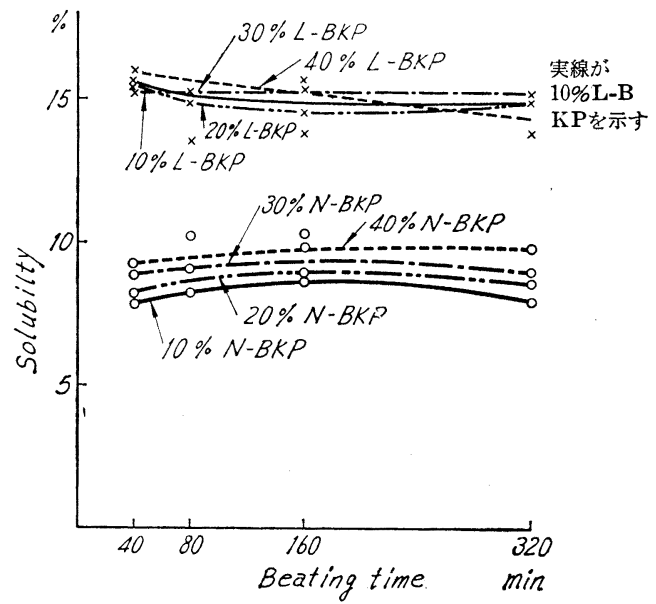

Fig. I-5
出時間の上昇に従い值は高くなり，乙かも，L-BKP も N-BKP もともに前に記したそれぞれのピークのあ たりで差が大きくなるが大差がない。

次に，Base に吒解度の異なるものを配合し，へミ セルロースの抽出状沉を検討した。すなうう L-BKP に L-BKP を配合した時のへミセルロースは，吒解度 を強化したものの配合を特に增加する傾向が見られな かった。ただし，L-BKPに N-BKP を配合する場合 には，配合率を増すにしたがっていく分抽分量が增す 傾向にあった。これはむしろ当然のように考劣られる。

(Fig. I-5)

II. a. Pebble mill で L-BKP を 10, 20, 40, 80 および 160 分吒解し，それぞれハンドシートを 作り紙質について試験検討を加えた。

Relation between tensile strength, bursting strength tearing strength, folding strength oil absorbency, opacity etc. and freeness of hand sheets.

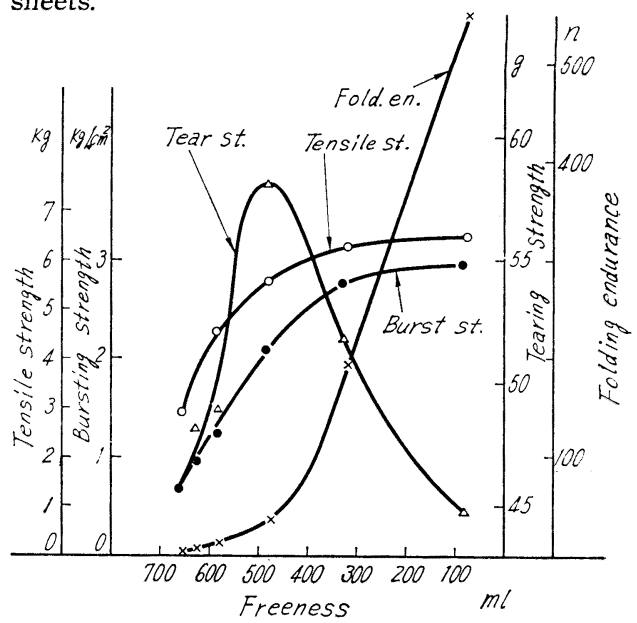

Fig. II a-1

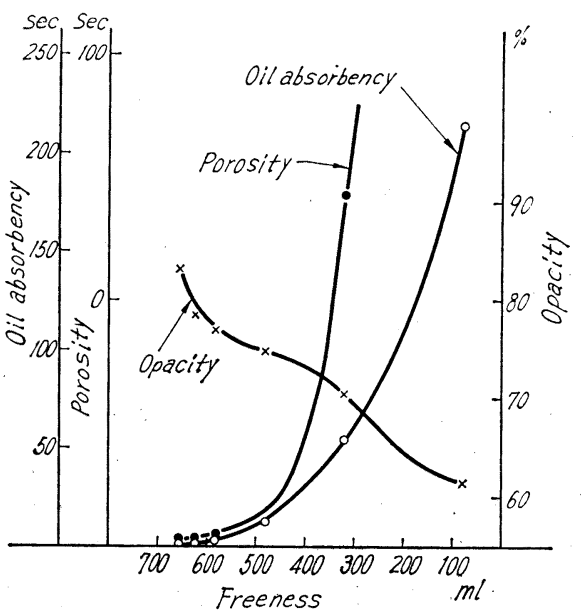

Fig. II a-2 
測定は, 米坪, 厚さ, 破裂度, 引張強度, 引裂さ度, 耐折度, 緊度, 透気度, 吸油度, 不透明度拉よびフリ ーネスなどについて行なった。曲線は Ia-1，Ia-2 に 示した。

こうして単独印解したもののフリーネスに基準を置 きこれをBase として以下比較検討した。

II.b. L-BKP を試験用 Valley beater で軽く 吒解したものを Base とし，これに L-BKP を Pebble mill で吒解したものを加えて, フリーネスの異なるものをつくり，紙質の検 討を行なった。

Table II b-1

\begin{tabular}{|c|c|c|c|}
\hline $\begin{array}{c}\text { Base. } \\
\text { slightly beaten } \\
\text { L-BKP }\end{array}$ & \multicolumn{2}{|c|}{$\begin{array}{c}\text { Blending ratio } \\
\text { of beaten pulps } \\
\text { L-BKP }\end{array}$} & $\begin{array}{c}\text { Canadian } \\
\text { standard } \\
\text { freeness c.c. }\end{array}$ \\
\hline $25 \%$ & \multirow{3}{*}{$\begin{array}{l}\text { beated } \\
80 \mathrm{~min} .\end{array}$} & $75 \%$ & 570 \\
\hline 50 & & 50 & 460 \\
\hline 75 & & 25 & 370 \\
\hline 15 & \multirow{3}{*}{$\begin{array}{l}\text { beated } \\
160 \mathrm{~min} .\end{array}$} & 85 & 540 \\
\hline 35 & & 65 & 380 \\
\hline 50 & & 50 & 280 \\
\hline 10 & \multirow{4}{*}{$\begin{array}{l}\text { beated } \\
320 \mathrm{~min} .\end{array}$} & (90 & 520 \\
\hline 20 & & 80 & 370 \\
\hline 30 & & 70 & 240 \\
\hline 50 & & 50 & 100 \\
\hline
\end{tabular}

のサンプルにについてそれぞれ試験した。

A. P. Arlov ${ }^{(22)}$ は針葉樹 S P, 晒広葉樹 S P, 晒広 葉樹K P，などを使用しで PFI mill でそれぞれ別個 に吒解して, 混合し物理的強度の比較を行なっている。 その中にカバ材の亜硫酸パルプは最も不透明を与える といっている。

Lennart Stockman, Ants Teder(23) らによれば未 晒 K P の離解性は加熱処理 $\left(90^{\circ} \mathrm{C}\right.$ に拉いて) しても影 響を受けないが末晒S P の離解性はかなり悪い。パル プが加熱処理で崩壊しない限り一定のフリーネスにす るのに必要な吒解エネルギーは変わらない，崩壊を伴 ならとわずかな吒解でフリーネスは低下し, 強度は減 退する。晒パルプの場合一定フリーネスにおける裂断 長は加熱処理によって減少する。減少の程度も乾燥パ ルプの場合よりもウエットパルプの方が大きい。E.J. Howard $^{(24)}$ によれば $\mathrm{NaOH}$ の溶液のマーセりゼーシ ョンは $6 \sim 12 \%$ で最大の溶解度を示す。また温度の低 い方が大さい。例えば 7\% NaOH 溶液のマーセリゼ ーションは $0^{\circ} \mathrm{C}$ で最大で, $100^{\circ} \mathrm{C}$ では括さない。また この変化は不可逆的でマーセル化した繊維素を非常に 高い温度（グリセリン中で $200^{\circ} \mathrm{C}$ 以上）に加熱しない
限り元に戻らない。マーセリゼーションの難易はCotton, K P , S Pなどによってそれぞれ異なると述べた。 これは別の文献ではあるが，春材部と秋材部の繊維に ついて紙葉の相違を検討しているものもある。

G. Van Nederveen, J. Isings ${ }^{(25)}$ らによれば Lampen millで吒解すると繊維が傷められ，切断される度 合いが大きいといっている。しかしわれわれはむしろ 規定通り吒解を進めた場合100分以上になると, ballの 落ら方が不均一になるように思うし，1回の仕込量が 少ないので今回は Pebble mill を使用することにした。

Mary L. Rollins ${ }^{(26)}$ の文献に第 1 次細胞膜の組成を 化学分析によって測定した数值が示されているから, ここに引用して括こう。(Table II. b-2) また東大農学 部平井信二教授の「木材構造について」と題する文献 中に主要針葉樹並びに広葉樹材の仮導管, 導管, 柔組 織などの構成割合が出ている。

Table II b-2 Chemical composition of cotton fiber and plimary wall

\begin{tabular}{|l|c|c|}
\hline & \multicolumn{2}{|c|}{$\%$ of dry weigth } \\
\hline \multicolumn{1}{|c|}{ Constituent } & Entire fiber & $\begin{array}{c}\text { Primary } \\
\text { wall }\end{array}$ \\
\hline Cellulose & 95.3 & 52 \\
Protein $(\mathrm{N} \times 6.25)$ & 1.0 & 12 \\
Pectin substances & 1.0 & 12 \\
Wax & 0.8 & 7 \\
Ash & 0.9 & 3 \\
Cutin (?) & - & 3 \\
Other (Organic & 1.0 & 11 \\
\hline \multicolumn{2}{|c|}{ acids, sugars) } & \\
\hline
\end{tabular}

な特，Mary L. Rollins 文献には沢山のキレイな顕 微鏡写真が出ている。基礎的な知識を得るために A. B. Wardrop ${ }^{(27)} の$ The fine structure of Conifer Tracheid に関するもの，また Bengt G. Rånby(2)(3) のセルロースミセルに関するものなど貴重な多くの文 献がある。

J. A. Van den Akker ${ }^{(28)}$ W. Boyd Campbell(1) らは製紙用繊維ではほとんど大部分の水酸基は水素結 合に供されて，シート形成にあたり繊維間の結合に役 立っていることを分光化学的に検討されたり，また， セルロース結合には有効面積, 接触, 水素結合の 3 つ が，重要な事柄として指摘し，論法を展開している。

繊維の微細部分についてますます研究を深め, 製造 されるそれぞれの製品に最も適した，しかもパルプ歩 留と品質の向上とコストの遁減について一番妥当な処 理を行なっていきたいものである。

さて，L-BKP を用いて吒解度のちがういくつかの 
Relation between physical properties and freeness of handsheets. (Blended L-BKP and L-BKP)

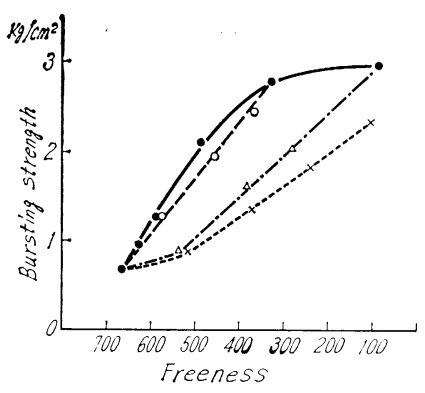

Fig. IIb-1

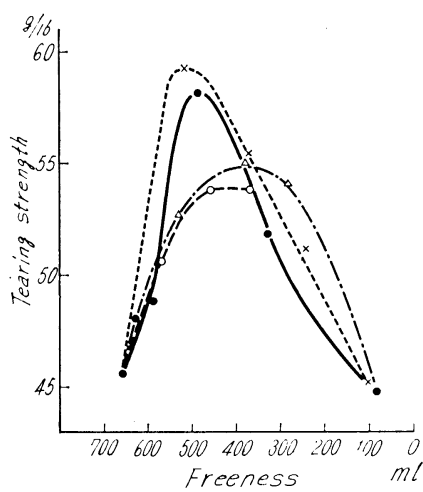

Fig. II b-3
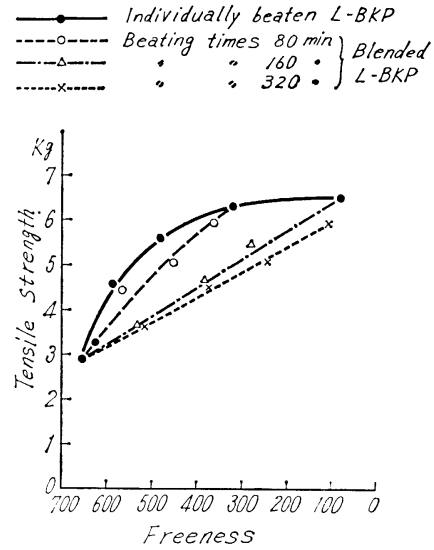

Fig. IIb-2

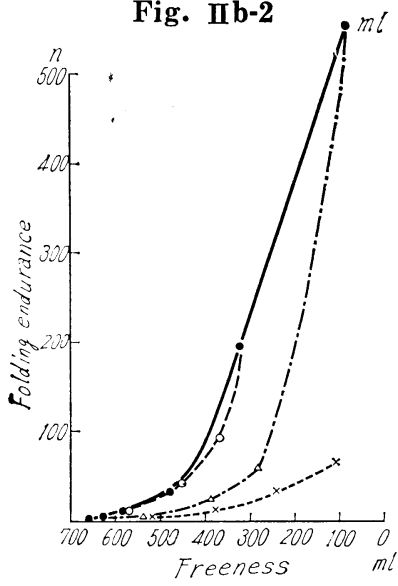

Fig. II b-4

ごとき）を配合してフリーネスに基 礎を和き紙質試験を行なった。

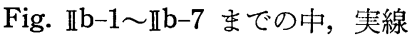
で示したものは L-BKP を単独印解 して得た曲線で，それぞれ Fig. IIa1, Fig. Ia-2 に示したものである。 なおBaseは は-BKPを試験用Valley beater で C.s.f. $660 \mathrm{cc}$ 飞吒解した ものであった。

結果の概略を述べると，破裂度， 引張強度, 耐折度などはともに単独 吒解のものの方が優位にあり，また 吒解度の低いものよりもある程度強 く進めたものを配合したものほど香 しくない傾向を示している。引裂度 は C.s.f. 350 100cc位までは別配合 のものに優位が見られ, C.s.f. 550 $400 \mathrm{cc}$ 位までは 320 分吒解したもの の配合物之単独吒解のものの両方に 優位があった。透気性と吸油性は大 体同じような傾向にあり，すなわち 単独吒解のものより，160 分吒解の ものが，な和 320 分吒解のものが透 気性も, 油吸収度も低い傾向を示乙 た。不透明度は明かに単独吒解のも のは低く, 160 分吒解物配合の子の が高く, また 320 分吒解物配合のも のが一層高い傾向を示した。

II. c. L-BKP を試験用 Velley ものをつくり (IIa) これと比較するために，L-BKP に その一部をより強く叨解したもの (Table Ib-1に示す beater で軽く叨解したものを Base とし，別に同じ Iب-BKP を Pebble mill で 40，80，160，320 および

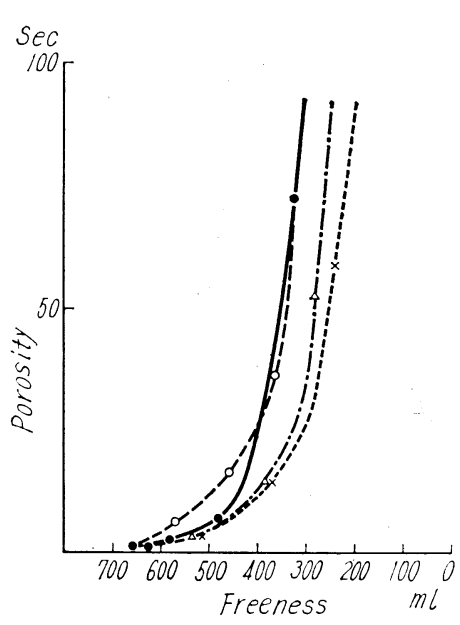

Fig. II b-5

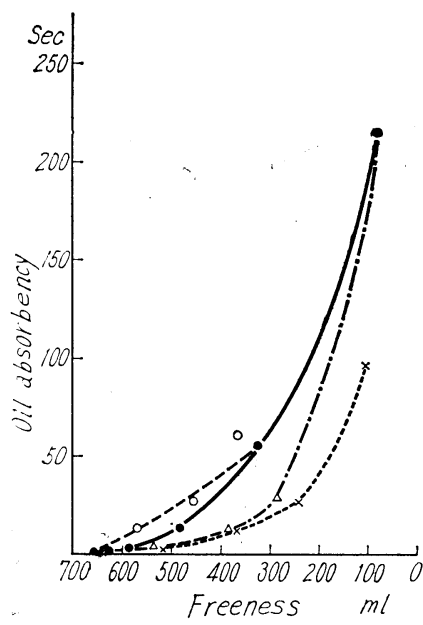

Fig. IIb-6

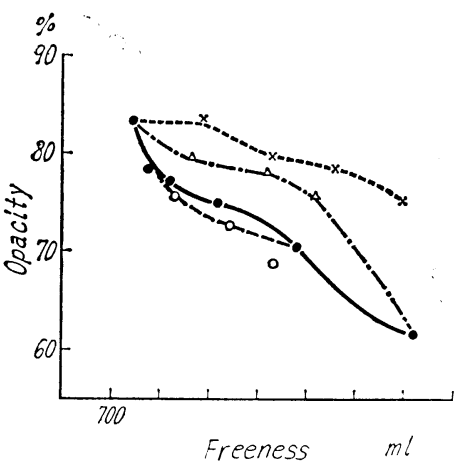

Fig. II b-7 
480 分吒解し，それぞれ 10，20，30，および 40\%を

L-BKP の Base に配合して紙質の变化を検討した。

Relation between physical properties and freeness of handsheets. (Blended L-BKP and L-BKP)
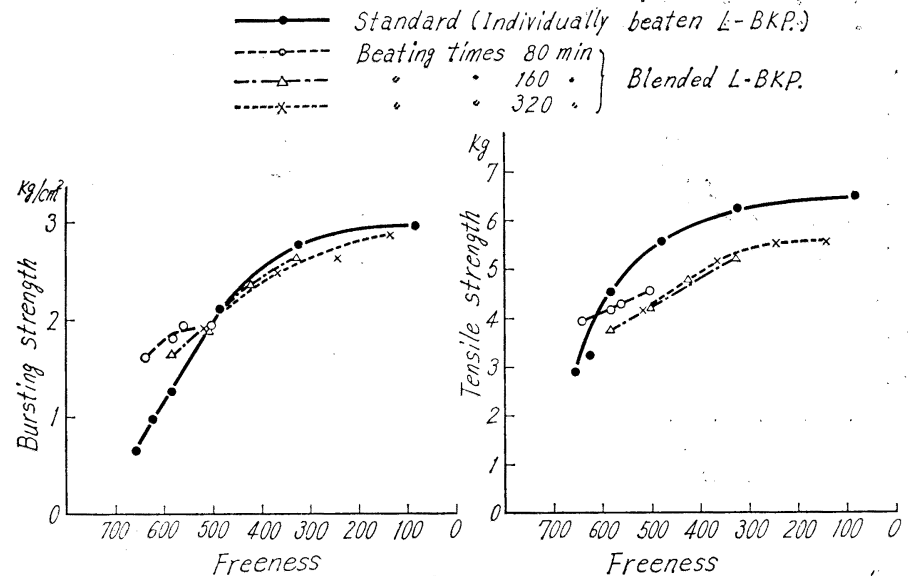

Fig. II c-1
Fig. II c-3

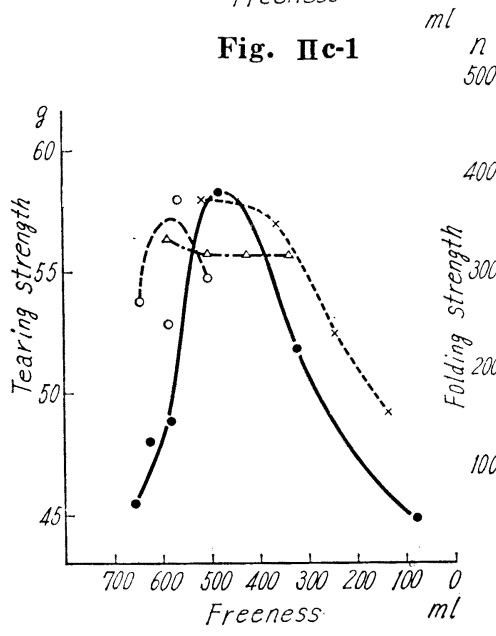

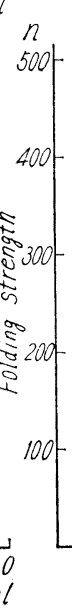

700 600
Freeness

Fig. III $c-2$
IIb とほぼ同様の傾向，例えば Fig. Ilb-2 の破裂度: 曲線を見てもわかるように，別吒解ものの配合率を増

したものほど強度が高い傾向にあり， また，吒解度を進めたものを配合し たものほど単独吒解のものより低い 価を示す傾向にある。ただし， 480 分も吒解を強化したものの配合は土全 く低下していた。 320 分吒解したも のを配合したものではN-BKPを 320 分吒解したものを配合したもの よりは，L-BKPを 320 分叨解した ものを配合した場合の方がむしろ高 い価を出す傾向にあった。Fig. IIc-2 の引張試験も； Fig. Ic -4 の耐折度 も同様な傾向にあり, II -3 の引裂度 曲線図では 500〜 400cc 吅解のあた りにピークがあるように思われる。 Ic は I b のチェックでもあるが $I c$ サンプルの調成は Id と同時試験 を行なったもので，Ic はむしろ Id との比較を考虑したものである。

II. d. L-BKP を試験用 Valley beaterで軽く叨解したものを Base とし，これに N-BKP を Pebble mill で 40, 80, 160 および 320 分吅 解し，それぞれ 10，20，30，およ び $40 \%$ Base に配合して紙質の

\section{変化を検討した。}

配合するものを N-BKP にした点 が IIc とちがうところである。Fig. Id $-1 \sim \mathbb{I d}-7$ は, その曲線図であるc，
Fig. II $\mathbf{c}-4$

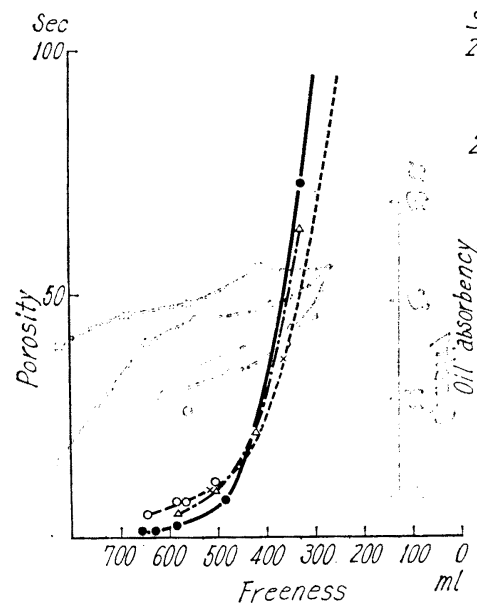

Fig. II c-5

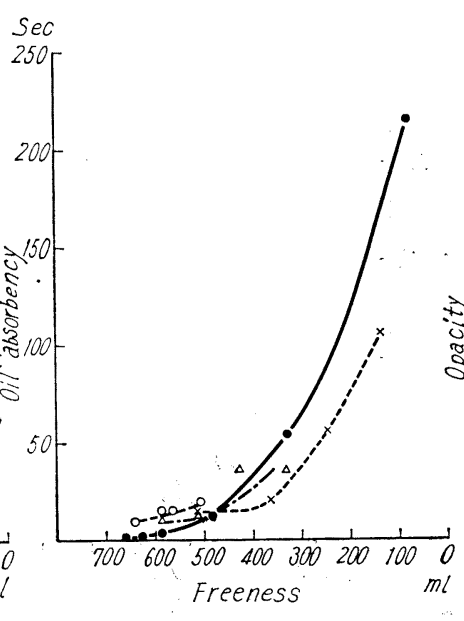

Fig. II c-6

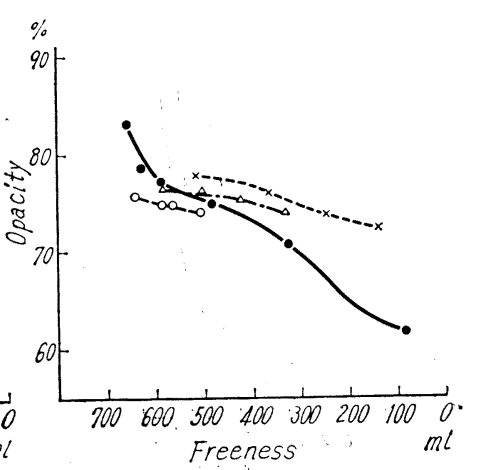

Fig. II c-7 
Relation between physical properties and freeness of handsheets. (Blended L-BKP and N-BKP)
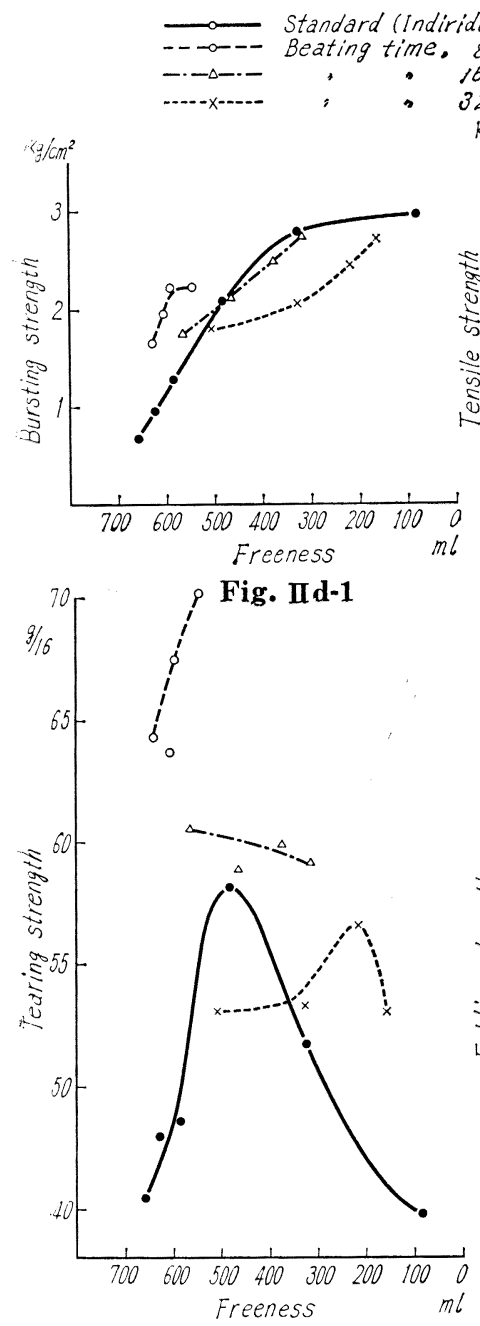

Fig. IId-3

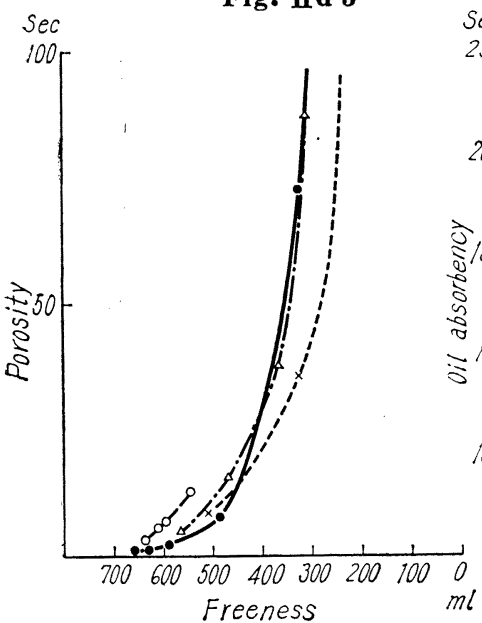

Fig. IId-5

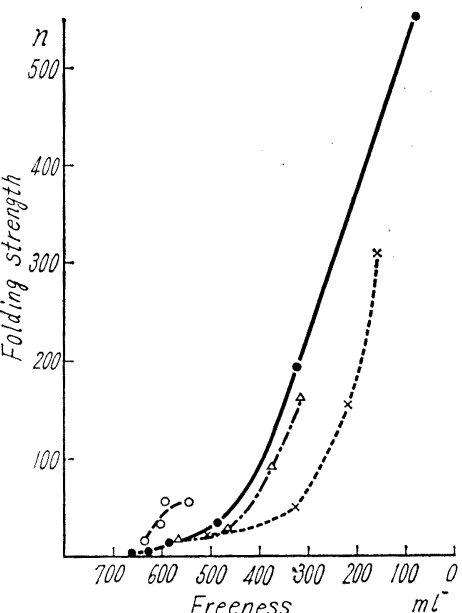

Fig. II d-4
N-BKP は繊維長も長いしまた 稀アルカリによって抽出される物 質中には六炭糖が多いから第 1 級 アルコールの OH をもつものが 多いので, 第 2 級アルュール $\mathrm{OH}$ のみをもつL-BKP より瀻維接着 力が大きいといことは文献中にも 発表されている。繊維が長いとい うことは単繊維では明らかに接着 面積が大さいと考光られる。まず Fig. Id -1〜 Id -7 について概要を 記气ら。

Fig. IId-1 の破裂度を見ると NBKP の配合の増加炕したがって 値が増し, 160 分吒解ぐらいまで は急速に大さくなったが，それ以 上 320 分までは横ばい状態のよう であった。引張り強度, すなわち Fig. IId-2 もだいたい破裂度と同 様であったっ耐折度は吒解度とと もに增加した。引裂き度も N-BK P の配合増加とともに高くなった。 これは 40 分の吒解を終わったあ たりで最も高い価を示した。なお IC拉よび Id に扔いて，配合した パルプはいずれも $40 \%$ 以下であ った。

次に L-, N-BKP 配合紙葉中の アルカリ抽出物量と 2,3 の物理 的性質について比較して見よう。 Id-8 は Base にL-BKPを配合

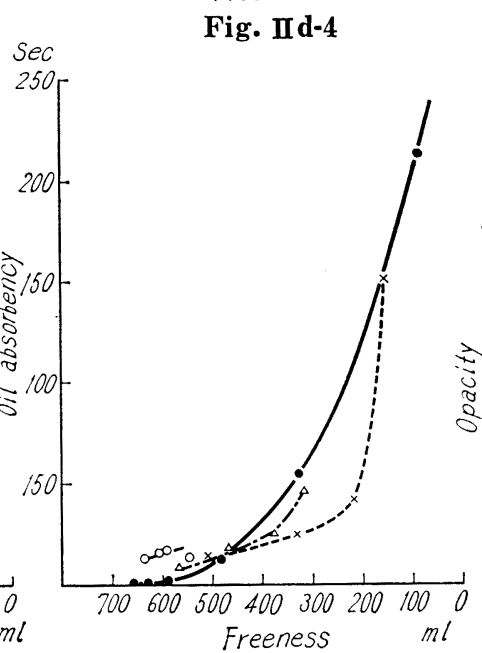

Fig. II d-6

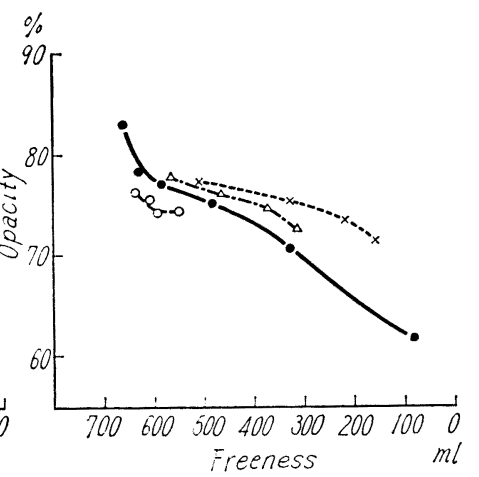

Fig. II d-7 


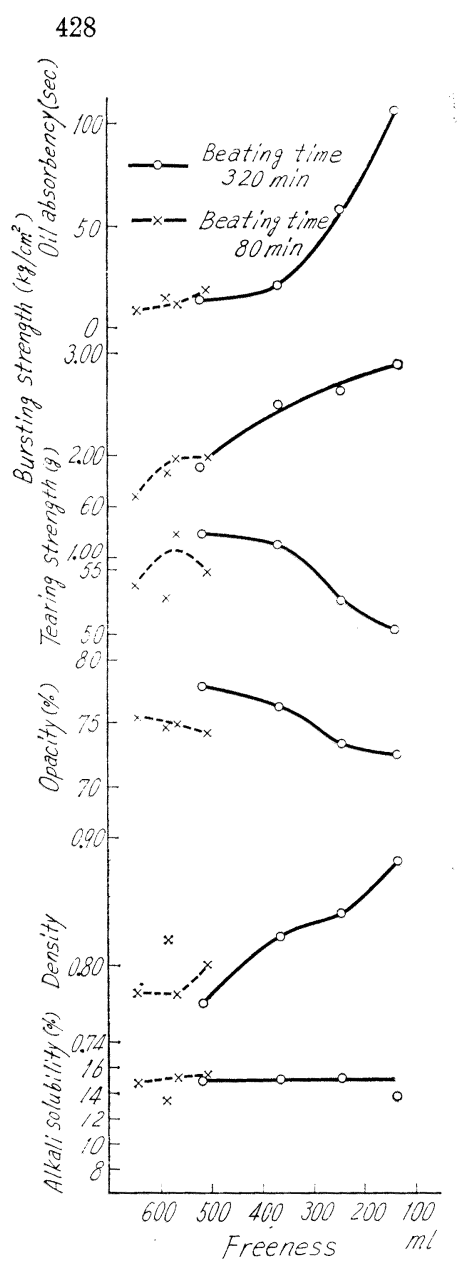

Fig. II d-8

Relation between physical properties, Hemicellulose and freeness of handsheets. (Blended L-BKP and L-BKP)

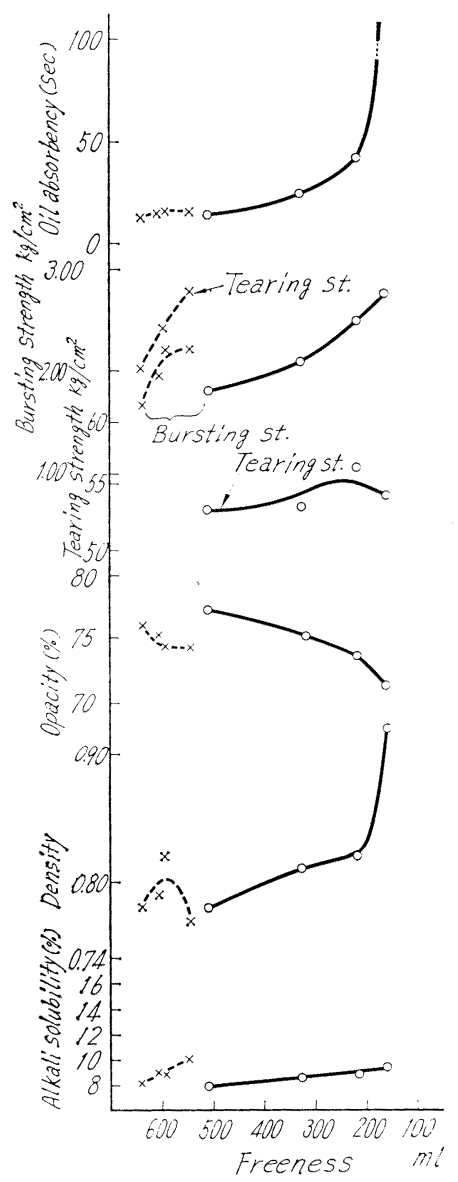

Fig. II d-9

Relation between physical properties, Hemicellulose and freeness of handsheets. (Blended L-BKP and N-BKP)

を左右するものは, 樹種, パルプ化 処理法, 繊維長, 太さ，細胞膜厚さ など瀻維の形態的な考兄と抄紙技術 などを総合的に考慮しなければなら ないことは，すでに一言した通りで ある。一層破裂強度の高い紙を望む ならば，単繊維の強度以上に強勒な 接着力を有つ接合剤の添加が望まし w。

II. e. N-BKP とL-BKP を混 合してから Lampen mill で吒解し, 紙質について検討を行なった。

手抄シートは次のような配合で作 った。

Blending ratio of fibers

\begin{tabular}{|c|c|c|}
\hline & $\begin{array}{c}\text { N-BKP } \\
(\%)\end{array}$ & $\begin{array}{c}\text { L-BKP } \\
(\%)\end{array}$ \\
\hline$(1)$ & 80 & 20 \\
$(2)$ & 72 & 28 \\
$(3)$ & 64 & 36 \\
$(4)$ & 56 & 44 \\
$(5)$ & 48 & 52 \\
$(6)$ & 40 & 60 \\
$(7)$ & 32 & 68 \\
$(8)$ & 24 & 76 \\
$(9)$ & 16 & 84 \\
$(10)$ & 8 & 92 \\
$(11)$ & 0 & 100 \\
\hline
\end{tabular}

以上のサンプルによる試験表から (1)(2)(10)括よび(11)について曲線図を作 って見ると Fig. IIe-1〜 Ie-5 のよう

したものであり，Id-9 は Base に N-BKPを配合し たものである。そして各々実線で表示したものは，元 れぞれ 320 分吒解したものを配合したもので，点線表 示は 80 分吒解したものを配合した場合の曲線である。 Hemicell としては L-BKP より抽出されたものが高 く，N-BKP ょり抽出されたものは低い。

320 分, 80 分両吒解に上る吸油度, 破裂度, 不透 明度および緊度などは L-BKPを添加したものも， N-BKP を配合したものも大体似ているが，引裂度の 又は 80 分吒解の場合も 320 分吒解の場合も, L-BKP 配合之N-BKP 配合に标いてかなりちがっている。こ れは繊維の形態と一ミセルロースの本質的な相違に大 きな原因があるものと思われる。

へミセルロースは破裂強度を高めるために効果的な 物質では㟧るが，すべてではない。一般に抄紙の良否
である。サンプル(3)〜 (9)末でによって得た数值はほと んど(1)々(11)が画く曲線の範囲内に包含されたので省略 した。吒解はどの配合率のものも全部 $10,20,40$ およ び 80 分行なったが， N-BKP $80 \%$ を含有するものは 80分叮解によってフリーネスは急激泜下した。しか しL-BKP は乞れほど大きく低下しなかった。破裂度, 引張り強度，耐折度については N-BKP 配合の多いも のが高い值を示しており，引裂き度については，吒解 度を 40 分以上にする場合, N-BKP も, L-BKP も同 様になる傾向にあった。ただし，Lampen mill 使用 の場合である。

ここに示したようにN-BKPの多いものとかL-BKP の多いものとか一方に片寄っている場合, 実際上 N-, L-を別々に印解取扱いすることは普通の紙質を得る場 合一般に行なわれていることであるが，この試験の結 
Relation between physical properties and freeness handsheets. (Beated after blending)

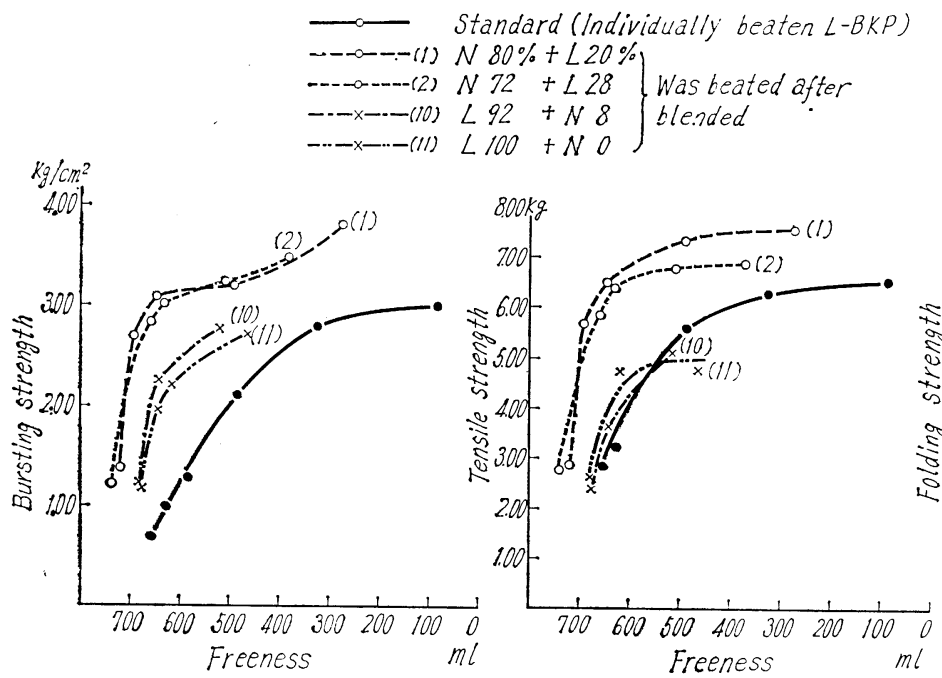

Fig. IV-1

Fig. IV-2

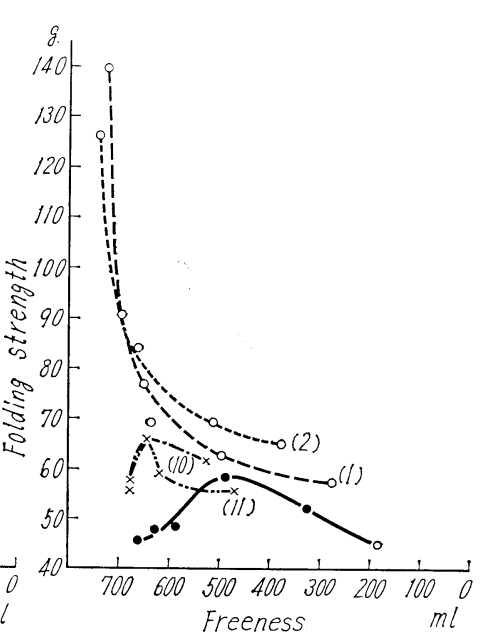

Fig. IV-3
Fig. $\mathbf{N}-4$

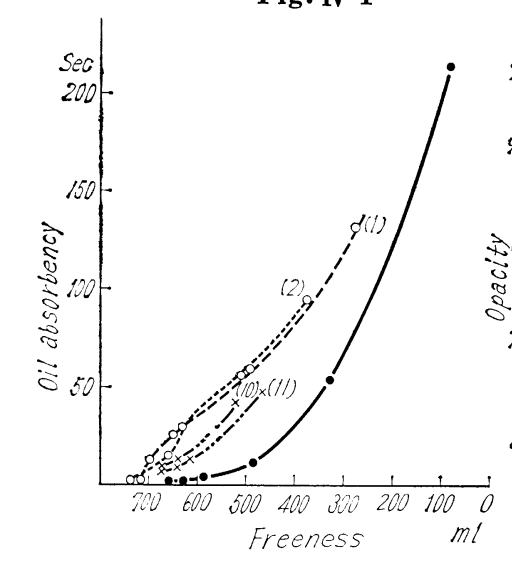

果から，それらの特徵の一つ例兄ば透明度の高いもの を要求する場合には両者を配合してから吒解すること が効果的のようである。

さて，Ia から Ie までの図表については，その 2,3 を説明するに止めたが，その他のものについては一見 すれば十分了解されると思う。

\section{III. ま と め}

（1）われわれの用いた N-BKP と L-BKP に括いて， アルカリ抽出量のピークは, N-BKPでは $\mathrm{NaOH}$ 溶液で $12 \%$ のところにまた，L-BKP では $8 \%$ の ところにあった。

（2）ごく軽く印解した L-BKPをBase とし，これ に Pebble mill でL-BKP と N-BKP を別々にか なり強く吒解したものを配合したとき，40\%以下 の配合に打いては N-BKP の場合も L-BKP の場
Fig.I-5

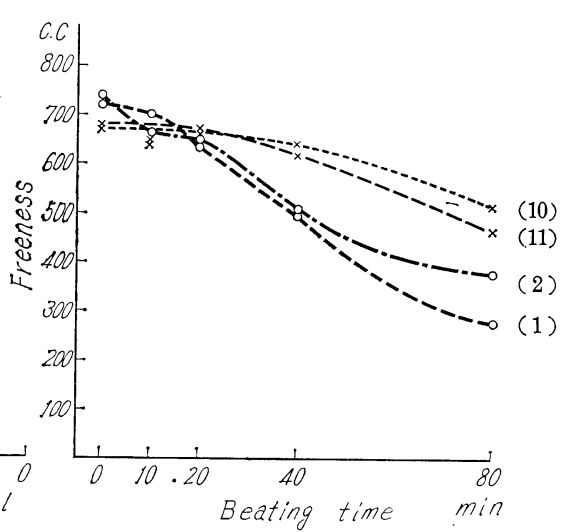

Fig. IV-6
合も大差なく, また L-BKP を単独で吒解したも のを同一フリーネスの状態下では比較すると破裂 度, 引張り強度, 耐折度などは単独吒解したもの の方が高い価を示す傾向にあった。しかし引裂き 度についてはある部分に別々吒解後配合したもの が高い価を示した。不透明度は, 別々吒解後配合 したものに高い価を示す傾向が見られた。

(3) N-BKP と L-BKP を配合して Lampen millで 吒解した場合のものと， L-BKP を Pebble mill で単独吒解したものとを比較して見ると, 同一フ リーネスの下では, Lampen mill で吒解したも のの方が強度に括いて比較的勝り, 不透明度は低 い傾向にあった。これは繊維に与兄る Beating の 状態が Lampen と Pebble で異なっているとい らことのよのである。 
（4）吒解ということは抄紙上必要欠くべからざる一 工程ではあるが総てではない，同様に一ミセル口 一スというものも抄紙上その効果を無視するわ放 にはいかないが，といっていミセルのみが物理的 性質の総てを左右するものでもない。結局, へミ セルによる強度を考虑するならば単独印解では破 裂度, 引張強度, 耐折度などに有効であり, 一層 の強さを望むならばへミセル以上強鞄な接着剈 を使用すべさである。

また引裂度と不透明度の高いものを欲するなら， この試験のようにその一部を強く吒解したものを バインダー的に使用することが好ましい上うに思 う。勿論紙質への影響は吒解処理のみで決するも のでなく, 原料, 蒸解, 精製抒よび抄造の全般に ついて総合的な配㕍が必要である。

終わりに臨み, 本試験を行ならに当たり, 種々ご助 言を賜わった元東京工業試験所長工学博士岡田元先生 に事心より感謝の意を表する次第であります。

\section{参 考 文 献}

1) W. Boyd Campbell: TAPPI 42, No. 12 999 1001 Dec. 1959.

2) Bengt G. Rånby: TAPPI Vol. 35 No. 2 53 58 Feb. 1952.

3) Bengt G. Rånby: Die Makromolekulare Chemie. Band XII Heft Sept. 1954.

4) Asunman, Saara \& Steenberg Börje: Svensk Papperstidn, 61, No. 18B, 686 95. Oct. 1958.

5) H. W. Emerton: Fundamentals of beating proces BP \& BIRA Kenley 1957.

6) James O. Thompson John W. Swanson and Louis E. Wise, TAPPI Vol. 36, No. 12, Dec. 1953.

7) Ferdinand Wultch \& Rudlf Shmut: TAPPI 44, 44, No. 1 38 42, Jan. 1961.

8) John A. Mcpherson \& Olov E. Öhrn: Svensk papperstidn. 63, No. 12.1960.

9) Francis D. Ratlift: TAPPI. Vol. 32 No. 8 Aug. 1949.
10) James D. Wethern: TAPPI. Vol. 35. No. 6, June, 1952 .

11) Manual N. Fineman: Paper mill news. Vol. 26. No. 49.1953.

12) L. G. Cottrall: British paper trade J. Aug. Sept. 1954.

13) Russel Nolson: TAPPI Vol. 43. No. 4. April 1960.

14) Dr. Louis E. Wise: Paper Ind. 37. No. 11. Feb. 1956.

15) Olov E. Öhrn \& Barbo F. Enström: Svensk papperstidn. 63, No. 22.1960.

16) John A. Mopherson \& Ohov. E. Öhrn: Svensk papperstidn. 63, No. 211960.

17) Göran E. Annergren \& Sven A. Rydholm : Svensk papperstidn. 20, No. 20. Oct. 1959.

18) Bengt Leopold: TAPPI 44, No. 3. 232. 1961.

19）戸田久路，木島常明，浜田忠平，紙分協会誌， Vol. 15. No. 2. Feb. 1961 •

20) James P. Casey: Pulp \& Paper. Vol. II.

21) Otto Kress \& Bialkowsky: P. T. J. 93, No. 20. Nov. 12. 1931. p. 35 44. Wilfred Gallay TAPPI Sept. 1950. Vol. 33. No. 9.

22) A. P. Arlov: Svensk papperstidn. 66, No. 9 May 1963.

23) Lennart Stockman \& Ants Teder: Svensk papperstidn. 66, No. 20. Oct. 1963.

24) E. J. Howard: Pulp and Paper Mag. Can. Vol. 54. No. 5. 1953.

25) G. Van Nederveen and J. Isings : TAPPI Vol. 37. No. 3. March 1954.

26) Mary L. Rollins : Analytical Chemistry. Vol. 26, No. 4. April 1954.

27) A. B. Wardrop: Holz forschung 8. 12. 1954.

28) J. A. Van den Akker: TAPPI 42, No. 12. Dec. 1959.

\section{データシート ただいま頌布中！}

$\begin{array}{lll}\text { B } 5 \text { 判 } & 150 \text { 枚 } & \text { じょうぶなバインダー付き } \\ \text { 頌 布 価 } & 800 \text { 円 } & \text { (送料協会負担) }\end{array}$

本データシートの内容は TAPPI Information Sheet を参考にして，わが国の内外における紙 パルプ関係の技術資料を集め，これを系統的に編集したものであります。

予約申込みは 8 月 10 日に締切りましたが，まだ残部がありますから，希望者は代金を添えて至 急打申込久下さい。 